UDK: 657.4

JEL: M41, M48

DOI 10.26906/eip.2019.2(73).1632

\title{
ACCOUNTING OF LIABILITY OF THE ENTERPRISE UNDER NATIONAL AND INTERNATIONAL ACCOUNTING STANDARDS
}

\author{
Olena Koba, PhD (Technical Sciences), Associate Professor \\ Yuliia Myronova, PhD (Economics) \\ Ilona Siroshtan, master student \\ Poltava National Technical Yuri Kondratyuk University
}

ORCID*0000-0003-1914-3119
ORCID**0000-0003-3934-6589
ORCID**0000-0003-1442-4472

\author{
(C) Koba O., 2019. \\ (C) Myronova Y., 2019. \\ (C) Siroshtan I., 2019.
}

Стаття отримана редакиієюю 14.05.2019 p.

The article was received by editorial board on 14.05.2019

Introduction. The liability is an integral part of any entity's business. The presence of obligations in an enterprise requires a clear understanding of their essence, composition, implementation of the correct classification and their reflection in accordance with the requirements of the current legislation. All funds raised must be returned in due time, and violations of certain repayment terms will have a negative impact on the financial performance of the activity, reduce solvency and profitability of the enterprise.

In addition, the state of settlement of obligations is influenced by the process of accounting reform in Ukraine, which takes place taking into account national peculiarities and acquired international experience.

Integration of Ukraine into the European and international environment facilitates the cooperation of national enterprises with foreign organizations in the field of trade, services and attraction of foreign investments. Foreign firms use international accounting and financial reporting standards. The content of the National Accounting Standards takes into account the economic, legal, tax characteristics of Ukraine and meets the main provisions of international accounting and financial reporting standards, but there are certain inconsistencies between national and international standards in terms of accounting obligations. This determines the relevance of research aimed at identifying and eliminating differences in accounting for the obligations of economic entities in accordance with international and national accounting standards.

An overview of the latest sources of research and publications. The order of displaying information about obligations of industrial enterprises was considered in the works by economists: O.V. Artiukh [1], T.V. Asmolova [2], D.O. Bondarenko [3], F.F. Butynets [4], S.F. Holov [5], S.M. Honcharuk [6], Yu.A. Kuzminskyi [7], N.V. Ovsiuk [8], T.V. Skovrunska [9] and others.

In particular, the interpretation of the essence and the study of the directions of classification types of the enterprise obligations are disclosed in the works by such scientists as: O.V. Artiukh [1], F.F. Butynets [4]. Problems of accounting for obligations under national and international accounting standards are devoted to the works: T.V. Asmolova [2], D.O. Bondarenko [3], S.F. Holov [5], S.M. Honcharuk [6], Yu.A. Kuzminskyi [7]. N.V. Ovsiuk [8] and T.V. Skovrunska [9] focused on harmonization of the national system of payroll calculations according to international standards.

According to the results of research on the organization of accounting obligations, it has been found that some of them need to be refined and improved, namely: certain theoretical provisions regarding the interpretation of the concept of «current liabilities» are controversial; the classification is complicated by the diversity of obligations; is a topical issue of harmonization of accounting of liabilities at national enterprises in the conditions of European integration and the application of international accounting and reporting standards.

The aim of the research. The aim of the research is to provide a comparative analysis of accounting of liabilities in accordance with International Accounting Standard 37 «Provisions, Contingent Liabilities 
and Contingent Assets» and the Accounting Standards 11 «Commitments», identifying differences in order to achieve harmonization between the given normative documents.

The main material and results. Commitment of an enterprise is an important condition for successful business conduct in modern conditions, as they are considered as a source of financial resources for financing operational, investment and financial activities of enterprises.

The main normative documents in accordance with which the information on obligations in the accounting and reporting of enterprises in Ukraine is displayed are: Law of Ukraine «On Accounting and Financial Reporting in Ukraine» [10], National Accounting Standards 1 «General the requirements for financial statements» [11], the Accounting standards 11《Liabilities» [12].

According to the Law of Ukraine «On Accounting and Financial Reporting in Ukraine» [10] and National Accounting Standards 1 «General the requirements for financial statements» [11], an obligation is an enterprise debt that arose as a result of past events and the repayment of which is expected to lead to a reduction in the resources of the enterprise embodying economic benefits.

In foreign countries accounting for liabilities is made in accordance with the provisions of International Accounting Standard 37 "Provisions, Contingent Liabilities and Contingent Assets" [13]. According to this normative document, an obligation is an existing obligation of an entity that results from past events and the settlement of which, in expectation, will result in the extinction of the resources of the entity that embody economic benefits.

So, the interpretations of the essence of the notion «obligation» in accordance with national and international accounting standards are similar.

Scope of application of IAS 37 «Provisions, Contingent Liabilities and Contingent Assets» [13] and Accounting Standards 11 «Commitments» [12] also vary. (Table 1).

\section{Scope of the Accounting standards 11 «Liabilities» and IAS 37 «Provisions, Contingent} Liabilities and Contingent Assets»

\begin{tabular}{|l|l|}
\hline Regulatory document & \multicolumn{1}{c|}{ Scope } \\
\hline $\begin{array}{l}\text { Accounting standards } 11 \\
\text { «Liabilities» [12] }\end{array}$ & $\begin{array}{l}\text { 1. Applied by enterprises, organizations and other legal entities, regardless } \\
\text { of ownership (except for budgetary institutions and enterprises that, according to } \\
\text { the law, make financial statements in accordance with international financial } \\
\text { reporting standards). }\end{array}$ \\
$\begin{array}{c}\text { 2. It is applied taking into account peculiarities of estimation and } \\
\text { disclosure of information about obligations, established by other accounting } \\
\text { regulations (standards). }\end{array}$ \\
$\begin{array}{l}\text { IAS 37 «Provisions, Contingent } \\
\text { Liabilities and Contingent } \\
\text { Assets» [13] }\end{array}$ & $\begin{array}{l}\text { Applies to all entities to account for collateral, contingent liabilities and } \\
\text { contingent assets, except those that are the result of contracts to be executed, } \\
\text { except when the contract is burdensome; to which the scope of another standard } \\
\text { applies. }\end{array}$ \\
\hline
\end{tabular}

Accounting standards 11 «Liabilities»is applied taking into account the peculiarities of accounting for liabilities that are presented in other accounting regulations. International standard is not applicable in the sphere covered by other standards.

In addition, IAS 37 «Provisions, Contingent Liabilities and Contingent Assets» is indicated when another standard refers to a specific type of security, contingent liability or contingent asset, an entity applies that standard. instead of this standard. For example, some types of collateral are also dealt with in the standards for: building contracts (IAS 11 «Construction Contracts»); income taxes (IAS 12 «Income Taxes»); lease (IAS 17 «Leases»).Since IAS 17 «Leases» does not contain any specific requirements for operating lease agreements that become burdensome, then IAS37 «Provisions, Contingent Liabilities and Contingent Assets» applies in such cases; employee benefits (IAS 19 «Employee Benefits»); insurance contracts (IFRS 4 «Insurance Contracts»). However, this IAS applies to those collateral, contingent liabilities or contingent assets of the insurer other than those arising from its contractual obligations and rights under insurance contracts and which are subject to the scope of IFRS.

In accordance with Accounting standards 11 «Liabilities» [12], a liability is recognized if its valuation can be reliably determined and there is a likelihood of future economic benefits diminished as a result of its repayment. If the previously recognized liability is not repayable at the balance sheet date, its amount is included in the income of the reporting period. 
In accordance with IAS 37 «Provisions, Contingent Liabilities and Contingent Assets» [13], provision should be recognized if: an entity has an existing obligation (legal or constructive) as a result of a past event; it is probable that the outflow of resources that embody economic benefits will be necessary for and fulfilment of the obligation; you can reliably estimate the amount of the obligation. Both in international and domestic practice, a liability is recognized and reflected in accounting, provided that its assessment can be reliably determined and the disposal of resources that embody economic benefits will occur.

An interpretation of the main terms that are specified in the national and international standards for accounting for enterprise obligations provides in the table 2.In addition, in each of the standards under consideration, there are concepts whose analogues are not in another standard. A list and interpretation of these concepts are presented in Table 3.

According to the information in tables 2 and 3, it can be argued that the complex notion of the «obligation» in Accounting standards 11 «Liabilities»is not presented, however, the definition of the terms of the long-term and current obligation is given. IAS 37 «Provisions, Contingent Liabilities and Contingent Assets» does not make such a division of the term «obligation» but decoded its value in its entirety.

The definitions of «provision security» and «agreed contract» have the same interpretation in both standards. The term «contingent liability» in the national standard and «constructive obligation» from the international standard are the same in content but have different names.

Table 2

Comparison of the meaning of the terms used in the Accounting Standard 11 «Liabilities» and the International Accounting Standard 37 «Provisions, Contingent Liabilities and Contingent Assets»

\begin{tabular}{|c|c|c|}
\hline The term & Accounting standard 11 «Liabilities» [12] & $\begin{array}{lccr}\text { International } & \text { Accounting } & \begin{array}{c}\text { Standard } \\
\text { «Provisions, } \\
\text { Contingent } \\
\text { Liabilities }\end{array} \\
\text { Contingent Assets» [13] } & & \end{array}$ \\
\hline Liabilities & $\begin{array}{l}\text { Long-term liabilities are all liabilities that are } \\
\text { not current liabilities. }\end{array}$ & $\begin{array}{l}\text { A liability is an existing obligation of an entity } \\
\text { that results from past events and the settlement } \\
\text { of which, in expectation, will result in the } \\
\text { extinction of the economic resources of the } \\
\text { entity that embody economic benefits. }\end{array}$ \\
\hline $\begin{array}{l}\text { Provision of } \\
\text { Security }\end{array}$ & $\begin{array}{l}\text { Provision of Security - an obligation with an } \\
\text { indefinite amount or maturity on the balance } \\
\text { sheet date. }\end{array}$ & $\begin{array}{l}\text { Security - a commitment with an indefinite } \\
\text { term or amount. }\end{array}$ \\
\hline $\begin{array}{l}\text { Contingent } \\
\text { liability }\end{array}$ & $\begin{array}{l}\text { An unexpected obligation is: } \\
\quad-\text { an obligation that may arise as a } \\
\text { result of past events and the existence of } \\
\text { which will be confirmed only when one or } \\
\text { more uncertain future events occur or will not } \\
\text { occur, over which the company has no full } \\
\text { control; or } \\
\quad-\text { a present obligation arising from } \\
\text { past events but not recognized as it is unlikely } \\
\text { that an obligation to settle a liability will } \\
\text { require the use of resources that embody } \\
\text { economic benefits or because the amount of } \\
\text { the obligation can not be reliably determined. }\end{array}$ & $\begin{array}{l}\text { Conditional obligation is: } \\
\quad-\quad \text { a possible liability arising out } \\
\text { of past events and the existence of which is } \\
\text { confirmed only after one or more uncertain } \\
\text { future events, which are not fully controlled by } \\
\text { the entity, will occur or will not occur, or } \\
-\quad \text { an existing obligation arising } \\
\text { out of past events but not recognized because: } \\
\text { there is no likelihood that the release of } \\
\text { resources that embody economic benefits will } \\
\text { be necessary to repay the obligation, or the } \\
\text { amount of the obligation can not be estimated } \\
\text { reliably. }\end{array}$ \\
\hline Agreed contract & $\begin{array}{l}\text { Agreed contract is a contract, costs (which can } \\
\text { not be avoided) that exceed the expected } \\
\text { economic benefits of this contract. }\end{array}$ & $\begin{array}{l}\text { Agreed contract is a contract whereby the } \\
\text { inevitable costs of repayment of the obligation } \\
\text { exceed the expected economic benefits from the } \\
\text { contract. }\end{array}$ \\
\hline
\end{tabular}


Table 3

Interpretation of the missing terms in the analyzed standards $[12,13]$

\begin{tabular}{|c|c|}
\hline Regulatory document & Application \\
\hline \multirow{3}{*}{$\begin{array}{l}\text { Accounting standard } 11 \\
\text { «Liabilities» }[12]\end{array}$} & $\begin{array}{l}\text { Current liabilities - liabilities that will be settled during the operating cycle } \\
\text { of an enterprise or should be repaid within twelve months from the balance } \\
\text { sheet date. }\end{array}$ \\
\hline & $\begin{array}{l}\text { Amount of redemption is the undiscounted amount of cash or cash } \\
\text { equivalents that is expected to be paid to repay the liability in the ordinary } \\
\text { course of business. }\end{array}$ \\
\hline & $\begin{array}{l}\text { Present value is the discounted amount of future payments (less the amount } \\
\text { of expected reimbursement) expected to be required to settle a liability in the } \\
\text { ordinary course of business. }\end{array}$ \\
\hline \multirow{5}{*}{$\begin{array}{l}\text { International Accounting } \\
\text { Standard } 37 \text { «Provisions, } \\
\text { Contingent Liabilities and } \\
\text { Contingent Assets» }[13]\end{array}$} & $\begin{array}{l}\text { An obligating event is an event that creates a legal or constructive } \\
\text { obligation, which results in the entity having no real alternative to fulfilling } \\
\text { the obligation. }\end{array}$ \\
\hline & $\begin{array}{l}\text { Legal obligation - an obligation arising out of: } \\
\text { - the contract (due to its explicit or implicit conditions); } \\
\text { - legislation, or } \\
\text { - another act of the law. }\end{array}$ \\
\hline & $\begin{array}{l}\text { Constructive obligation - an obligation that is a consequence of an entity's } \\
\text { actions when: } \\
\text { - the entity has indicated to the other parties that it will assume certain } \\
\text { responsibility in accordance with the procedure established by its past } \\
\text { practice, published by politicians or by a sufficiently concrete current } \\
\text { statement; } \\
\text { - as a consequence, the entity has created a reasonable expectation on } \\
\text { the part of other parties that it will fulfil these obligations. }\end{array}$ \\
\hline & $\begin{array}{l}\text { Contingent asset is a possible asset that arises from past events and the } \\
\text { existence of which is confirmed only after one or more uncertain future } \\
\text { events, which are not fully controlled by the entity, will occur or will not } \\
\text { occur. }\end{array}$ \\
\hline & $\begin{array}{l}\text { Restructuring - a program that is planned and controlled by management } \\
\text { personnel and which significantly changes: } \\
\text { - volume of activity carried out by the entity, or } \\
\text { - a way of doing this activity. }\end{array}$ \\
\hline
\end{tabular}

The presence of non-analogous terms in both standards indicates the difference between the general accounting system and the regulatory framework of Ukrainian and international legislation.

Table 4 presents the classification of liabilities of the enterprise in accordance with Accounting Standard 11 «Liabilities» and IAS 37 «Provisions, Contingent Liabilities and Contingent Assets»to compare existing types of commitments.

As approaches to the classification of liabilities in accounting standards (Table 4), the classification of liabilities that is applicable in Ukraine (in accordance with Accounting Standard 11 «Liabilities») distinguishes the following types of liabilities: long-term, current and unforeseen obligations liabilities, future income, and, in accordance with international standards, liabilities are divided into current (shortterm) and non-current (long-term).

Conclusions. According to the results of the research, it was found that Accounting Standard 11 «Liabilities» and IAS 37 «Provisions, Contingent Liabilities and Contingent Assets» have both common and distinctive features.

Common is the use and reflection in these accounting standards of terms such as «commitment» and «security», as well as the definition of «commitment». 
Table 4

Classification of «obligations» in accordance with the Accounting Standard 11 «Liabilities» and International Accounting Standard 37 «Provisions, Contingent Liabilities and Contingent Assets»

\begin{tabular}{|c|c|c|}
\hline Regulatory document & \multicolumn{2}{|c|}{ Classification of «obligations» } \\
\hline \multirow{11}{*}{$\begin{array}{l}\text { Accounting Standard } 11 \\
\text { «Liabilities» }[12]\end{array}$} & \multirow{4}{*}{ long-term } & long-term bank credits \\
\hline & & other long-term liabilities \\
\hline & & deferred tax liabilities \\
\hline & & long-term security \\
\hline & \multirow{5}{*}{ short-term } & Short-term bank credits \\
\hline & & $\begin{array}{l}\text { current payables for long-term obligations, for } \\
\text { goods, works, services, for settlements with the budget, } \\
\text { including income tax, insurance calculations, payroll } \\
\text { calculations, settlements with participants, settlements } \\
\text { from internal settlements }\end{array}$ \\
\hline & & short-term bills issued \\
\hline & & current security \\
\hline & & other current commitments \\
\hline & \multicolumn{2}{|c|}{ contingent liabilities } \\
\hline & future rever & lues \\
\hline \multirow{3}{*}{$\begin{array}{l}\text { International Accounting } \\
\text { Standard } 37 \text { «Provisions, } \\
\text { Contingent Liabilities and } \\
\text { Contingent Assets» }[13]\end{array}$} & \multicolumn{2}{|c|}{$\begin{array}{l}\text { collateral - recognized as a liability (assuming that it can be measured } \\
\text { reliably), since it is an existing obligation and it is probable that repayment } \\
\text { of this obligation will require the release of resources that embody economic } \\
\text { benefits; }\end{array}$} \\
\hline & \multirow{2}{*}{$\begin{array}{l}\text { contingent } \\
\text { liabilities } \\
\text { which are not } \\
\text { recognized as an } \\
\text { obligation } \\
\text { because they are } \\
\text { either: }\end{array}$} & $\begin{array}{l}\text { possible commitments (since it remains to be confirmed } \\
\text { whether an entity has an existing obligation that may } \\
\text { result in the release of resources that embody economic } \\
\text { benefits), or }\end{array}$ \\
\hline & & $\begin{array}{l}\text { an existing obligation that does not meet the } \\
\text { criteria for recognition in this Standard (as there is no } \\
\text { probability of retirement of resources that embody the } \\
\text { economic benefits necessary to repay the obligation, or } \\
\text { the amount of the obligation could not be estimated with } \\
\text { sufficient certainty). }\end{array}$ \\
\hline
\end{tabular}

The difference is that: Accounting Standard 11 «Liabilities» considers liabilities, and IAS 37 «Provisions, Contingent Liabilities and Contingent Assets»- collateral; in accordance with IAS 37 «Provisions, Contingent Liabilities and Contingent Assets», the provision is reflected in the balance sheet as part of the short-term or long-term liabilities, while in Ukraine there is no provision for the separation of securities in the timing of their involvement.

Some of the issues regarding the registration of this object remain unclear in the current Accounting Standard 11 «Liabilities»: there are no separate terms and concepts, nor their interpretation (obligatory event, legal obligation, constructive (actual, traditional) liabilities, current debt, reliable estimate of obligation, best estimate of expenses necessary to repay current debts at the balance sheet date). Solving these problematic issues is the subject of further research.

\section{REFERENCES:}

1. Artiukh O.V. Accounting: a tutorial. Odessa, 2014. 305 p.

2. Asmolova T.V., Syrtseva S.V. Features of accounting for obligations under national and international accounting standards: a comparative aspect. Economic Sciences. 2015. Issue 12 (45). Part 1. P. $15-21$.

3. Bondarenko D.O. Features of accounts payable in the transition to international standards. The official website of Zhytomyr Scientific Accounting School Franz Butynets. URL: http://zsas.zhitomir.org/ru/forum.

4. Butynets F.F. Theory of Accounting: Textbook. Zhytomyr: Ruta, 2003. 444 p.

\begin{tabular}{l|l}
\hline 106 & Economics and Region № 2 (73) - 2019-PoltNTU
\end{tabular}


5. Holov S.F., Kostiuchenko V.M. Accounting in accordance with international standards: examples and comments: practice manual. Kyiv: Libra, 2001. 840 p.

6. Honcharuk S.M., Voitovych N.V. Harmonization of accounting of obligations in enterprises in Ukraine in the context of transition to international standards. Young scientist 2017. № 12 (52). P. 596-600.

7. Kuzminskyi Yu.A. Automation of operational accounting and control of international economic operations: monograph. Kyiv: KNEU, 2001.268 p.

8. Ovsiuk N.V., Radchenko O.Yu. Employee benefits for Accounting Standard 26 and IAS 19: A comparative aspect. Problems of the theory and methodology of accounting, control and analysis. 2012. № 3 (24). P. 360-368.

9. Skovrunska T.V., Tyvonchuk S.V. Harmonization of the national system of payment of wages according to international standards. Economic Sciences. 2013. Issue 10 (4). P. 229-236.

10. On Accounting and Financial Reporting in Ukraine: Law of Ukraine dated July 16, 1999 № 996-XIV / Verkhovna Rada of Ukraine. URL: https://zakon.rada.gov.ua/laws/show/996-14(application date: 20.04.2019).

11. National Accounting Standard 1 «General Requirements for Financial Statements» : Order of the Ministry of Finance of Ukraine dated February 7, 2013 № 73 / Ministry of Finance of Ukraine. URL: https://zakon.rada.gov.ua/laws/show/z0336-13 (application date: 20.04.2019).

12. Accounting Standard 11 «Liabilities»: Order of the Ministry of Finance of Ukraine dated January 31, 2000 № 20 / Ministry of Finance of Ukraine. URL: https://zakon.rada.gov.ua/laws/show/z0085-00 (application date: 20.04.2019).

13. International Accounting Standard 37 «Provisions, Contingent Liabilities and Contingent Assets» : Standard dated January 1, 2012 / Council on International Accounting Standards. URL:https://zakon.rada.gov.ua/laws/show/9 29_051(application date: 20.04.2019).

\section{UDK: 657.4}

JEL: M41, M48

Коба Олена Вікторівна, кандидат технічних наук, доцент. Миронова Юлія Юріївна, кандидат економічних наук. Сіроштан Ілона Олегівна, магістрантка. Полтавський національний технічний університет імені Юрія Кондратюка. Облік зобов'язань підприсмства відповідно до національних та міжнародних стандартів бухгалтерського обліку. Розглянуто порядок формування інформації та відображення господарських операцій з обліку зобов'язань підприємства відповідно до норм національних і міжнародних стандартів бухгалтерського обліку. Проведено порівняльний аналіз нормативних документів у розрізі тлумачення сутності, визнання та класифікації зобов'язань підприємства. Виявлено відмінності у сфері застосування положень (стандартів) бухгалтерського обліку. Установлено спільні й відмінні риси методики обліку зобов'язань підприємства. Спільними рисами є: використання і відображення у стандартах бухгалтерського обліку таких термінів, як «зобов'язання» $\mathrm{i}$ «забезпечення», а також визначення поняття «зобов'язання». Відмінність полягає у тому, що: П(С)БО 11 «Зобов’язання» розглядає зобов'язання, а МСБО 37 «Забезпечення, умовні зобов'язання та умовні активи»- забезпечення. До того ж МСБО 37 «Забезпечення, умовні зобов'язання та умовні активи» передбачає розподіл забезпечень при відображенні в балансі на коротко- й довгострокові зобов'язання, тоді як в Україні взагалі не передбачено поділ забезпечень за часом їх залучення. У результаті розгляду підходів до класифікації зобов'язань у стандартах обліку встановлено, що класифікація зобов'язань, яка застосовується підприємствами в Україні (відповідно до П(С)БО 11 «Зобов’язання»), виокремлює довгострокові, поточні, непередбачувані зобов'язання, доходи майбутніх періодів, а відповідно до міжнародного стандарту (МСБО 37 «Забезпечення, умовні зобов'язання та умовні активи») зобов'язання поділяються лише на поточні (короткотермінові) й непоточні (довготермінові).

Визначено основні неврегульовані питання з обліку зобов'язань згідно з нормами діючого П(С)БО 11 «Зобов'язання» (на відміну від МСБО 37 «Забезпечення, умовні зобов'язання та умовні активи»): відсутні окремі терміни і поняття, а також їх тлумачення (подія, що зобов'язує; юридичне зобов'язання; конструктивне (фактичне, традиційне) зобов'язання; теперішня заборгованість; достовірна оцінка зобов'язання; найкраща оцінка видатків, необхідних для сплати теперішньої заборгованості на дату балансу).

Ключові слова: зобов'язання, забезпечення, національні стандарти бухгалтерського обліку, міжнародні стандарти бухгалтерського обліку, визнання, класифікація зобов'язань. 
UDK: 657.4

JEL: M41, M48

Koba Olena, PhD (Technical Sciences), Associate Professor. Myronova Yuliia, $\mathrm{PhD}$ (Economic Sciences). Siroshtan Ilona, master student. Poltava National Technical Yuri Kondratyuk University. Accounting of liability of the enterprise under national and international accounting standards. The article deals with the order of formation of information and reflection of operations on accounting of obligations of the enterprise in accordance with the norms of national and international accounting standards. The comparative analysis of normative documents in the context of the interpretation of the essence, recognition and classification of obligations of the enterprise is carried out. The common and distinctive features of the method of accounting for the given object are established.

Key words: obligations, ensuring, national accounting standards, international accounting standards, recognition, classification of obligations.
UDK: 657.4

JEL: M41, M48

Коба Елена Викторовна, кандидат технических наук, доцент. Миронова Юлия Юрьевна, кандидат экономических наук. Сироштан Илона Олеговна, магистрантка. Полтавский национальный технический университет имени Юрия Кондратюка. Учет обязательств предприятия согласно национальным и международным стандартам бухгалтерского учета. Рассмотрен порядок формирования информации и отражения хозяйственных операций по учету обязательств предприятия в соответствии с нормами национальных и международных стандартов бухгалтерского учета. Проведен сравнительный анализ нормативных документов в разрезе толкования сущности, признания и классификации обязательств предприятия. Выявлены общие и отличительные черты методики учета данного объекта.

Ключевые слова: обязательства, обеспечения, национальные стандарты бухгалтерского учета, международные стандарты бухгалтерского учета, признания, классификация обязательств. 